\title{
Bio-efficacy of Bacillus subtilis against Damping off Disease in Brinjal
}

\author{
Deepak Awasthi $^{{ }^{*}}$, Mukesh Srivastava ${ }^{1}$, Shubha Trivedi ${ }^{1}$, Abhishek Mishra $^{1}$, \\ Supriya Dixit ${ }^{1}$, Saurabh Govind Rao ${ }^{1}$, Virendra Singh ${ }^{1}$ and Yatindra Srivastava ${ }^{1}$ \\ ${ }^{1}$ Department of Plant Pathology, C. S. Azad University of Agriculture and Technology, \\ Kanpur 208002, India. \\ Authors' contributions
}

This work was carried out in collaboration among all authors. All authors read and approved the final manuscript.

Article Information

DOI: $10.9734 / A R R B / 2019 / v 31 i 430053$

Editor(s):

(1) Prof. Wafaa Mohamed Shukry, Departement of Botany, Faculty of Science, Mansoura University, Mansoura, Egypt.

(2) Dr. George Perry, Dean and Professor of Biology, University of Texas at San Antonio, USA.

Reviewers:

(1) Dr. V. Vasanthabharathi, Annamalai University, Tamil Nadu, India.

(2) Hanan E. S. Ali, Cairo, Egypt.

Complete Peer review History: http://www.sdiarticle3.com/review-history/38502

Original Research Article

Received 27 November 2017

Accepted 26 January 2018

Published 29 March 2019

\begin{abstract}
Bacillus $s p$ is one of the biocontrol agents are extensively used in management of fungal diseases of crop plants, exhibiting mycoparasitism against a wide range of plant pathogens. In the present investigation Efficacy of Bacillus subtilis was tested against Pythium aphanidermatum under glass house and field conditions. With regard to the germination and seedling growth parameters, the treatment $\mathrm{T}_{2}$ (liquid formulation of Bacillus subtilis @10 ml/L) recorded the highest germination percentage $(92.59 \%)$, shoot length $(59.3 \mathrm{~cm})$, root length $(24.3 \mathrm{~cm})$, vigor index $(7740.52)$ and yield (22.67 mt/ha). This was followed by the treatments $T_{3}, T_{1}$ and $T_{4}$ in the decreasing order of merit. In the biometric observations also, $10 \mathrm{ml} / \mathrm{L}$ and $20 \mathrm{ml} / \mathrm{L}$ concentration of liquid formulation of Bacillus subtilis recorded statistically significant results. Observations on total protein content in brinjal plants treated with different concentrations of Bacillus subtilis revealed that treatment $T_{2}$ was found best in both field and glass house conditions yielded highest protein as $0.44 \mathrm{mg} / \mathrm{ml}$ and $0.30 \mathrm{mg} / \mathrm{ml}$ respectively. The least values of germination, growth parameters, protein content and yield were observed in untreated control.
\end{abstract}

Keywords: Biocontrol; phytopathogenic; Pythium aphanidermatum; Bacillus subtilis. 


\section{INTRODUCTION}

Brinjal (Solanum melongena L.) popularly known as eggplant is an important solanaceous crop of sub tropics and tropics. The brinjal is of much importance in the warm areas of Far East, being grown extensively in India, Bangladesh, Pakistan, China and the Philippines. It is also popular in Egypt, France, Italy and United States. In India, it is one of the most common, popular and principal vegetable crop grown throughout the country except higher altitudes. Brinjal has been cultivated in India for the last 4,000 years, although it is often thought of as a Mediterranean or mid-Eastern vegetable. The global area under brinjal cultivation has been estimated at 1.6 million ha with total production of brinjal fruit of about 4.2 million tons (FAO data, 2014). India accounts for about 8.7 million tons with an area of 0.53 million hectares under cultivation.

The disease which limit the production of brinjal includes Damping off, Alternaria blight, Late blight, Fusarium wilt, Phomopsis wilt, Cercospora Leaf spot, Bacterial wilt, Little leaf of brinjal etc.

Among the various diseases; Damping-off caused by Pythium aphanidermatum is one of the most widely spread and prevalent throughout the country causing considerable loss in India. The pathogen is soil borne in nature, also known as water mold. Pythium aphanidermatum overwinters in the soil as oospores, hyphae and/or sporangia, oospores can produce a germ tube and infect the plant directly, or, if the environment is favorable (that is an adequate amount of water is present), the oospore may produce sporangia, which in turn produce motile, bi-flagellate zoospores that swim to the host plant, encyst, and germinate. Various control measures which are generally used to manage the disease, are cultural practices, chemical, biological control and use of resistant varieties. Among these, use of resistant varieties is found to be most beneficial measure but development of new races of pathogen overcome resistance. Among cultural practices deep summer ploughing, destruction of diseased crop debris, crop rotation and use of soil amendments are recommended for the management of the disease. But all these cultural practices are not reliable to manage the disease in standing crop. Therefore, biological control has been adopted to minimize the disease severity.
Biological control is also likely to be more effective than disease control, that is based on synthetic chemicals. The complexity of interactions between organisms, the involvement of numerous mechanisms of disease suppression by a single microorganism, and the adaptness of most biocontrol agents to the environment in which they are used, all contribute to the belief that bio-control is more durable than synthetic chemical control $[1,2]$.

Among bio-control agents Bacillus subtilis is considered as potential biocontrol agent and plant growth promoter agent (PGPR) for many crops. Various mechanisms are involved in the biological control of fungal pathogens by PGPRs. These mechanisms include the production of secondary metabolites such as antibiotics, siderophores, hydrolytic enzymes, phytohormones, volatile extracellular metabolites, hydrogen cyanide and competition for nutrients, promotion of plant growth and, finally, induced resistance within the plants [3]. PGPR may also promote plant growth by providing nitrogen [4], simplifying nutrient uptake [5].

Bacillus is also identified as potential bio-control agent used as alternatives to pesticide since they achieve disease suppression without negative effects on user, consumer or the environment [6]. Plant associated bacilli are recognized either as saprophytes, or as biological control agents. The genus Bacillus includes a variety of important species used in the fermentation industry. Bacillus spp. are nonpathogenic, good secretors of proteins and metabolites, and easy to cultivate. Products currently available commercially include enzymes, antibiotics and insecticides.

The present study was undertaken with the main objective for assessing the efficacy of antagonistic rhizobacteria belonging to genus Bacillus against Pythium aphanidermatum.

\section{MATERIALS AND METHODS}

\subsection{Collection, Isolation, Purification and Identification of Pathogen}

Pythium aphanidermatum was isolated plant samples were collected from Brinjal field of vegetable farm of C.S. Azad University of Agri. \& Technology, Kanpur and adjoining farmer's field.. Cultural and Morphological characterizations was also done. 


\subsection{Isolation of Antagonistic Bacteria (Bacillus sp.)}

Serial dilution technique [7] was adapted for isolation of Bacillus sp. from rhizospheric soil samples collected from brinjal eco-system. Morphological and cultural characterization of isolated bacterial colonies were done.

For identification at species level purified cultures of bacterial bio-agents were send to ITCC, New Delhi. Based on the identification report bacterial bio-agents was identified as Bacillus subtilis and were used for further studies.

\subsection{Pathogenicity Test}

The inoculum of the isolates identified as Pythium apahnidermatum, based on their morphological and cultural characters was multiplied on sand maize meal medium [8] for 25 days at $25 \pm 1^{\circ} \mathrm{C}$. The inoculum thus obtained was mixed in sterilized soil @ $5 \%$ w/w and was filled in 8 inches diameter earthen pots, which were thoroughly cleaned with laboline detergent. In each of these pots 5 brinjal seedlings of a highly susceptible brinjal variety $(\mathrm{J}-2)$ were sown and kept in glass house during December 2015. For each isolate separate pots were used, and for each treatment 3 replications along with untreated control was maintained. The pots such sown were regularly observed for the appearance of the disease. Diseased seedlings from these pots were collected. These plants were used for re-isolation of the pathogen (isolate). The isolates obtained from these plants were compared with the original isolate with which these were inoculated.

\subsection{In vitro Screening of Antagonistic Bacteria}

To assess the in vitro effect of Bacillus subtilis against $P$. aphanidermatum a laboratory bioassay by using Dual culture technique [9] was conducted at Biocontrol Lab, Department of Plant Pathology, C. S. Azad University of Agriculture \& Technology, Kanpur. The antagonist $B$. subtilis was inoculated first with the help of sterilized inoculation loop from liquid bioformulations prepared with sterilized water (@ $5 \mathrm{ml} / \mathrm{l}, 10 \mathrm{ml} / \mathrm{l}$ and $20 \mathrm{ml} / \mathrm{l}$ ) and one day later, $5 \mathrm{~mm}$ disc from pathogen culture was inoculated since, $P$. aphanidermatum was fast growing. Observations were recorded when the control plates were completely covered by the mycelial growth of
$P$. aphanidermatum and percent growth inhibition was calculated using following formula -

Percent growth inhibition $=($ Mycelial growth in control - Mycelial growth in treatment / Mycelial growth in control) $X 100$

\subsection{Bio-efficacy of Bacillus subtilis against $\boldsymbol{P}$. aphanidermatum under In vitro Conditions}

To evaluate the bio- efficacy of antagonistic bacteria as seedling treatment against $P$. aphanidermatum, trials were conducted under greenhouse conditions (pot trial). The disease grading was done by following the scale proposed by Srivastava et al. [10]. Seedlings of brinjal (Var. J-2) were collected from Vegetable Farm, C.S.A.U.A.\&T, Kanpur. The seedlings were kept in a beaker $(100 \mathrm{ml}$ capacity). Bacterial suspension was prepared in sterile distilled water with a cell density of $9 \times 10^{8}$ $\mathrm{CFUml}^{-1}$. Different concentrations of liquid formulation of antagonistic bacteria viz., $\left(T_{1}\right)$ $5 \mathrm{ml} / \mathrm{kg}$ seed $\left(\mathrm{T}_{2}\right) 10 \mathrm{ml} / \mathrm{kg}$ seed $\left(\mathrm{T}_{3}\right) 20 \mathrm{ml} / \mathrm{kg}$ seed $\left(\mathrm{T}_{4}\right)$ Carbendazim 50\% WP @ $2 \mathrm{~g} / \mathrm{kg}$ and $\left(T_{5}\right)$ Control (sterilized distilled water) applied to the seedling in 3 replications for $12 \mathrm{~h}$ and then sown in earthen pots. Pots were kept under greenhouse conditions till the end of the experiment. For rating the bio-agent, the disease grading scale proposed by Srivastava et al. [10] was followed. Brinjal plants were also observed for phytotoxic symptoms (If any) such as chlorosis, necrosis, scorching, epinasty and hyponasty on $1,3,5,7$ and 10 days after treatment of Bacillus subtilis. The data on disease incidence and other biometrics were analyzed by using standard statistical techniques.

\subsection{Bio-efficacy of Bacillus subtilis against Pythium aphanidermatum under Field Conditions}

A field experiment was conducted at Research farm of C.S.A.U.A\&T, Kanpur to find out the effect of Bacillus subtilis as seedling treatment against $P$. aphanidermatum causing damping off on Brinjal crop in plot size $6.75 \times 3.60 \mathrm{mts}$. (24.3 sq.m. per treatment) in Randomized Block Design (RBD) with five treatments and three replications. The Brinjal seedlings (var. J-2) treated with liquid formulation of Bacillus subtilis $\left(9 \times 10^{8} \mathrm{cfu} / \mathrm{ml}\right) @ 5 \mathrm{ml} / \mathrm{kg}$ seed, $10 \mathrm{ml} / \mathrm{kg}$ seed, $20 \mathrm{ml} / \mathrm{kg}$ seed were sown in line in hot spot area 
(sick soil). The treated seedlings were kept for 24 hrs in shade and then sown. Carbendazim (Bavistin 50\% WP) @ $2 \mathrm{~g} / \mathrm{kg}$ of seed was treated and used for comparison and an untreated control was also maintained. The crop was maintained with judicial irrigation and all the agronomic practices and fertilizer. Effect of Bacillus subtilis on root length, shoot length, vigour index, yield/treatment and total leaf protein of brinjal crop was estimated. Seedling vigour index was calculated by using the formula as described by Baki and Anderson [11].

Vigour index $=$ (Mean root length + Mean shoot length) $X$ Germination (\%)

\subsection{Estimation of Total Protein of Brinjal Plants Treated with Different Concentration of Bacillus subtilis through Lowry Method}

\subsubsection{Total protein extraction}

Total leaf protein was extracted using method developed by Goggin et al. [12]. $0.5 \mathrm{~g}$ leaves of treated brinjal plants were frozen by liquid nitrogen, grinding to a fine powder using mortar and pestle then transferred to a fresh centrifuge tube. Two $\mathrm{ml}$ of extraction buffer (Tris- $\mathrm{HCl} 1 \mathrm{M}$, pH 8, EDTA, 0.25), SDS, 10\%, glycerol, 50\%) was added and mixed well. The content of the tubes were centrifuge at $12000 \mathrm{rpm}$ for $20 \mathrm{~min}$ at $4^{\circ} \mathrm{C}$. After centrifugation process supernatant was discarded. Mixed the pellets with $1 \mathrm{ml}$ of sample buffer $(80 \%$ Acetone, $0.07 \% \quad \beta$ mercaptoethanol and $2 \mathrm{mM}$ EDTA) and centrifuged at $12000 \mathrm{rpm}$ for 5 minutes. The

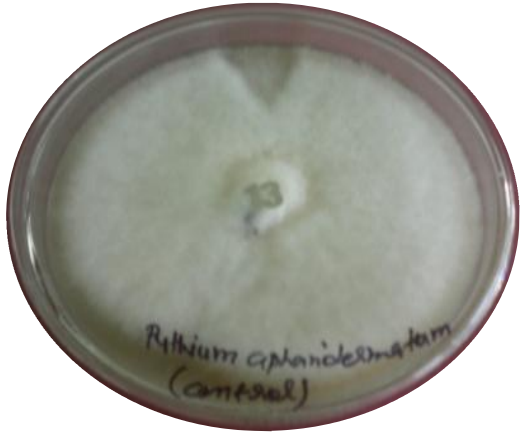

(A) process was repeated until all chlorophyll removed. Mixed clear pellet with milli $Q$ water and stored at $-20^{\circ} \mathrm{C}$. Protein concentration of all the samples was determined using Lowry assay [13].

\subsubsection{Protein quantification}

For quantification of protein content $1 \mathrm{mg} / \mathrm{ml}$ of BSA standard was used. Different dilutions of the standard were made. To each tube of standard and sample $2 \mathrm{ml}$ of complex forming reagent was added and kept for 10 minutes at room temperature. After 10 minutes of incubation period, $0.2 \mathrm{ml}$ of Folin-Ciocalteu reagent solution was added to each tube and incubated for 20-30 minutes at room temperature in dark. After incubation period sample absorbance was taken at $660 \mathrm{~nm}$ by using spectrophotometer (BioRad). Calibration curve was constructed by plotting absorbance reading on $\mathrm{Y}$ axis against standard protein concentration $(\mathrm{mg} / \mathrm{ml})$ on $X$ axis. Sample concentration was calculated using standard graph as a reference.

\section{RESULTS}

To obtained pure cultures of $P$. aphanidermatum from infected brinjal plants, isolations were made on PDA. Pure culture of fungal pathogen were maintained on Potato Dextrose Agar Medium using hyphal bit method [14]. The pathogen was identified on the basis of cultural and morphological characters. Based on the cultural and morphological characters on PDA, isolates was identified as $P$. aphanidermatum.

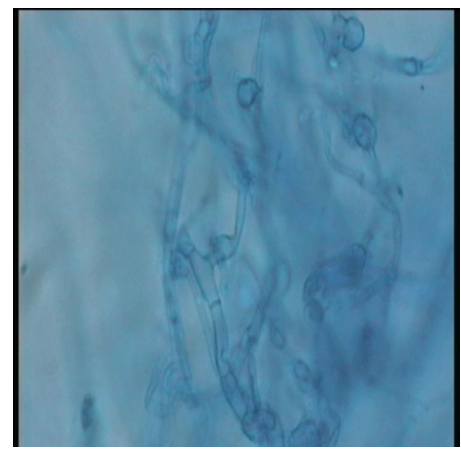

(B)

Fig. 1. P. aphanidermatum (A) Growth on PDA medium (B) Microscopic observation at $40 x$ 
The culture was found to be Pythium aphanidermatum by the characteristics such as colony color, sporangia consisting of a terminal complex of swollen hyphal branches of varying length; oogonia terminal, globus smooth with 24$29 \mu \mathrm{m}$ diameter. Antheridia terminal and intercalary of broadly sac shaped.

Based on the disease severity the isolate was found to be highly pathogenic with 97.5 percent damping-off incidence on brinjal. Further studies were conducted with this isolate of $P$. aphanidermatum.

Using serial dilution isolation techniques 50 distinct colonies were subculture on Nutrient Agar on the basis of colony morphology. The isolates which were found to be Gram-positive, rod-shaped, endospore-forming, motile when observed through sterio-binocular were considered as Bacillus subtilis. Moreover, they did not grow under strictly anaerobic conditions. The solitary colonies of the isolate on Nutrient agar after 3 days of incubation were small, round, opaque, spreading or non-spreading dull, circular with an irregular circumference and cream-colored. No diffusible pigment was produced. It was thus preliminarily characterized as members of the genus Bacillus which was further identified as Bacillus subtilis.

The results of in vitro studies revealed that Bacillus subtilis significantly reduced the mycelial growth of $P$. aphanidermatum with 71.1 percent reduction @10 ml/l $\left(\mathrm{T}_{2}\right)$ over control. Treatment $\mathrm{T}_{3}$ and $\mathrm{T}_{1}$ also reduced the growth of the pathogen as 66.6 and $61.1 \%$ respectively over control. The chemical treatment reduced the mycelial growth of the pathogen by 44.4 percent (Table 1).

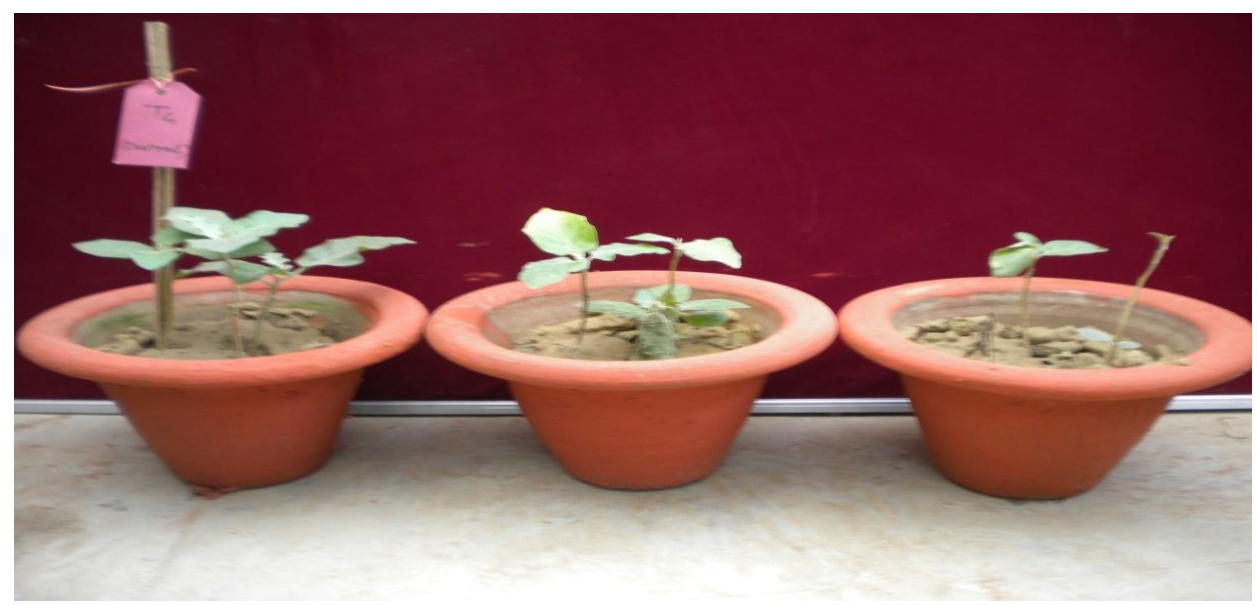

Fig. 2. Pathogenicity test of Pythium aphanidermatum on Brinjal seedlings (A) Untreated control (B \& C) Diseased seedlings

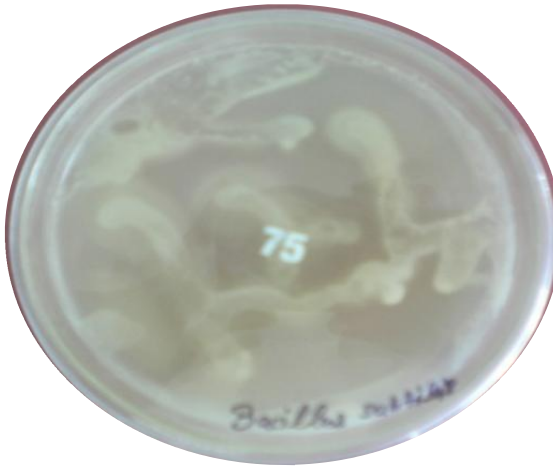

A

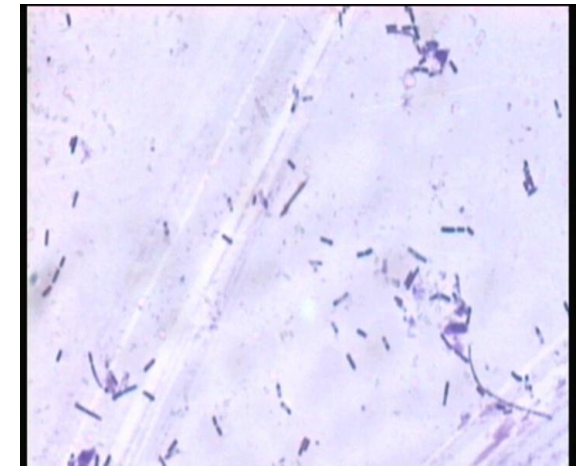

B

Fig. 3. Bacillus subtilis (A) Growth on Nutrient agar (B) Microscopic observation at 40x 


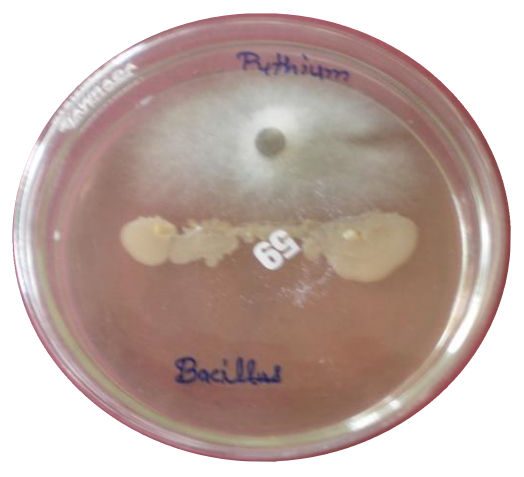

Bacillus subtilis $(5 \mathrm{ml} / \mathrm{l})$ $+P$.aphanidermatum

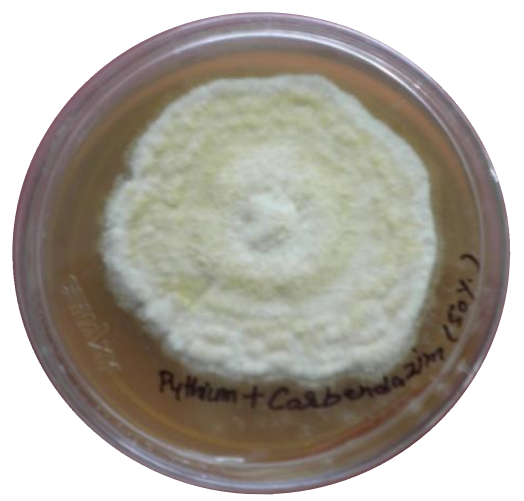

Carbendazim (50\%WP)

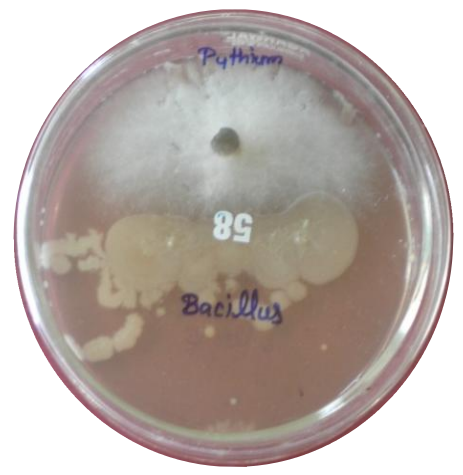

Bacillus subtilis $(10 \mathrm{ml} / \mathrm{l})+$ P.aphanidermatum

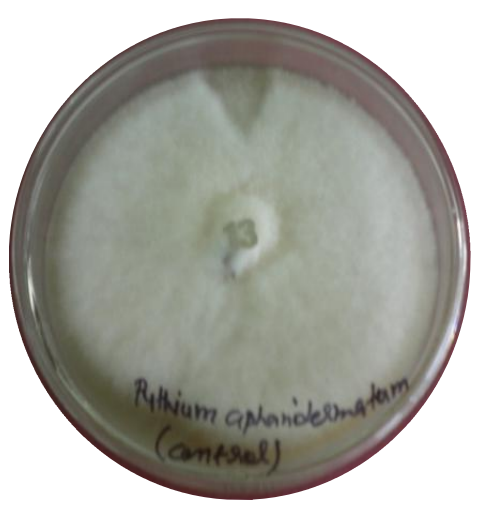

Control

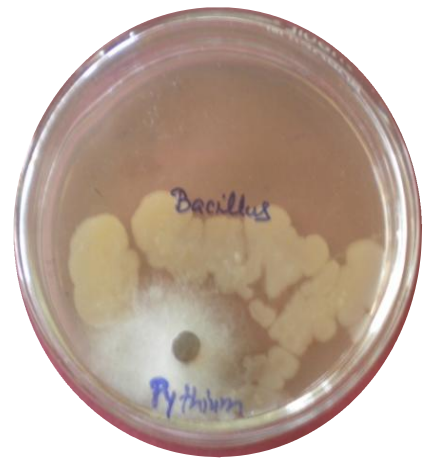

Bacillus subtilis $(20 \mathrm{ml} / \mathrm{l})+$ $P$. aphanidermatum

Fig. 4. Antagonism of Bacillus subtilis against $P$. aphanidermatum (Dual Culture)

Table 1. In vitro efficacy of Bacillus subtilis against $\boldsymbol{P}$. aphanidermatum

\begin{tabular}{|c|c|c|c|}
\hline S. no. & Treatment details & $\begin{array}{l}\text { Radial growth of } \\
P . \text { aphanidermatum (mm)* }\end{array}$ & $\begin{array}{l}\text { Percent growth } \\
\text { reduction }\end{array}$ \\
\hline$T_{1}$ & B. subtilis @5 ml/l seed & 35.0 & 61.1 \\
\hline $\mathrm{T}_{2}$ & B. subtilis@10 ml/l & 26.0 & 71.1 \\
\hline $\mathrm{T}_{3}$ & B. subtilis @20 ml/l & 30.0 & 66.6 \\
\hline $\mathrm{T}_{4}$ & Carbendazim 50\% WP @0.1\% conc. & 50.0 & 44.4 \\
\hline \multirow[t]{3}{*}{$\mathrm{T}_{5}$} & Untreated & 90.00 & - \\
\hline & & 0.23 & \\
\hline & $C D(p=0.05)$ & 0.50 & \\
\hline
\end{tabular}

${ }^{*}$ Mean of three replications

The results presented in Table 2 revealed the efficacy of $B$. subtilis under glass house condidtions. Among the various dosage levels treatment $\mathrm{T}_{2}$ (Seedling treatment with $B$. subtilis $@ 10 \mathrm{ml} / \mathrm{kg}$ seed) recorded the maximum germination $(83.33 \%)$ and significantly reduced the pre emergence and post emergence damping off disease on brinjal to the minimum
(16.6 and 20.0 percent pre and post emergence damping off respectively). Seedling treatment with B. subtilis @20 ml $/ \mathrm{kg}$ of seed also recorded significant results with that of $T_{2}$. Based on the results treatment $T_{2}$ was rated as "Highly Efficient (HE)". The maximum of 41.6 and 71.4 percent pre and post emergence damping off was observed in untreated control. 
Table 2. Bio efficacy of Bacillus subtilis for the management of $P$. aphanidermatum causing damping off on Brinjal (Pot tria)

\begin{tabular}{|c|c|c|c|c|c|c|c|}
\hline \multirow[t]{2}{*}{$\begin{array}{l}\text { Tr. } \\
\text { no. }\end{array}$} & \multirow[t]{2}{*}{$\begin{array}{l}\text { Treatment } \\
\text { details }\end{array}$} & \multirow[t]{2}{*}{$\begin{array}{l}\text { Germination } \\
(\%)\end{array}$} & \multicolumn{2}{|c|}{$\begin{array}{c}\text { Damping off incidence } \\
(\%)^{*}\end{array}$} & \multicolumn{2}{|c|}{$\begin{array}{c}\text { Disease control } \\
(\%)\end{array}$} & \multirow{2}{*}{$\begin{array}{l}\text { Rating of the } \\
\text { bio-efficacy } \\
\text { of } \\
\text { B. subtilis }\end{array}$} \\
\hline & & & $\begin{array}{l}\text { Pre } \\
\text { emergence }\end{array}$ & $\begin{array}{l}\text { Post } \\
\text { emergence }\end{array}$ & $\begin{array}{l}\text { Pre } \\
\text { emergence }\end{array}$ & $\begin{array}{l}\text { Post } \\
\text { emergence }\end{array}$ & \\
\hline$\overline{T_{1}}$ & $\begin{array}{l}\text { Seed treatment } \\
\text { with } B \text {. subtilis } \\
@ 5 \mathrm{ml} / \mathrm{kg} \text { seed }\end{array}$ & 68.3 & 31.6 & 46.3 & 24.0 & 35.1 & $\begin{array}{l}\text { Moderately } \\
\text { Efficient (ME) }\end{array}$ \\
\hline $\mathrm{T}_{2}$ & $\begin{array}{l}\text { Seed treatment } \\
\text { with } B \text {. subtilis } \\
@ 10 \mathrm{ml} / \mathrm{kg} \\
\text { seed }\end{array}$ & 83.3 & 16.6 & 20.0 & 60.0 & 71.9 & $\begin{array}{l}\text { Highly } \\
\text { Efficient (HE) }\end{array}$ \\
\hline $\mathrm{T}_{3}$ & $\begin{array}{l}\text { Seed treatment } \\
\text { with } B \text {. subtilis } \\
@ 20 \mathrm{ml} / \mathrm{kg} \\
\text { seed }\end{array}$ & 75.0 & 25.0 & 33.3 & 39.9 & 53.3 & Efficient (E) \\
\hline $\mathrm{T}_{4}$ & $\begin{array}{l}\text { Seed treatment } \\
\text { of Carbendazim } \\
50 \% \text { WP @ } \\
2 \mathrm{~g} / \mathrm{kg} \text { seed }\end{array}$ & 66.6 & 33.3 & 50.0 & 19.9 & 29.9 & -- \\
\hline \multirow[t]{2}{*}{$T_{5}$} & $\begin{array}{l}\text { Untreated } \\
\text { Control }\end{array}$ & 58.3 & 41.6 & 71.4 & -- & -- & -- \\
\hline & $\begin{array}{l}\text { SE } \\
C D(p=0.05)\end{array}$ & $\begin{array}{l}0.16 \\
0.34\end{array}$ & $\begin{array}{l}0.15 \\
0.33\end{array}$ & $\begin{array}{l}0.14 \\
0.34\end{array}$ & -- & -- & -- \\
\hline
\end{tabular}

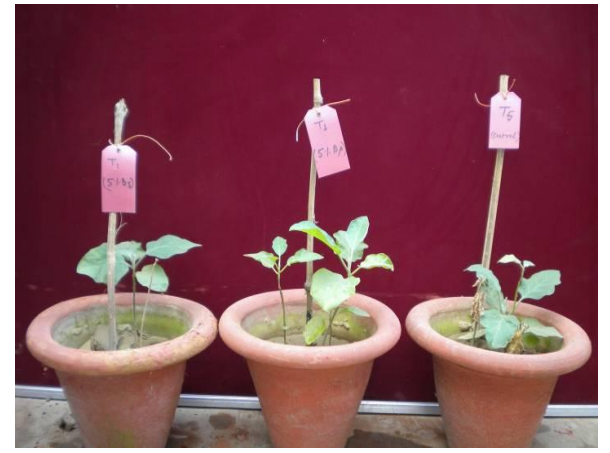

Seed treatment with $B$. subtilis @ $5 \mathrm{ml} / \mathrm{kg}$ seed (T1)

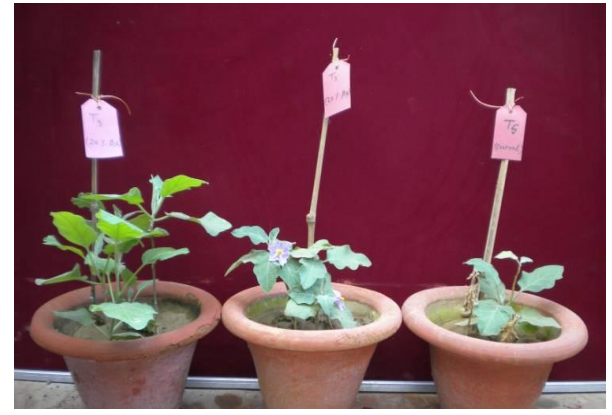

Seed treatment with B. subtilis @20 ml/kg seed (T3)

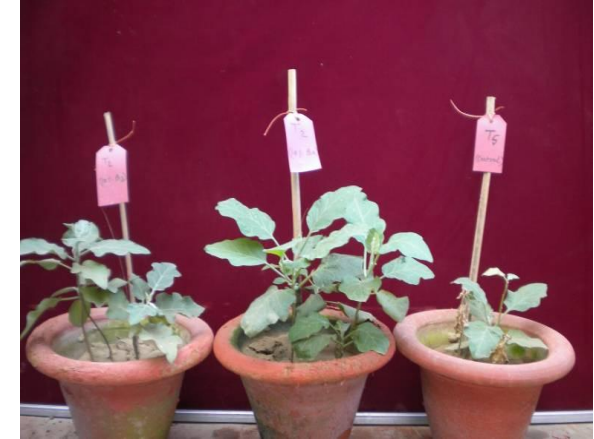

Seed treatment with B. subtilis @10 ml/kg seed (T2)

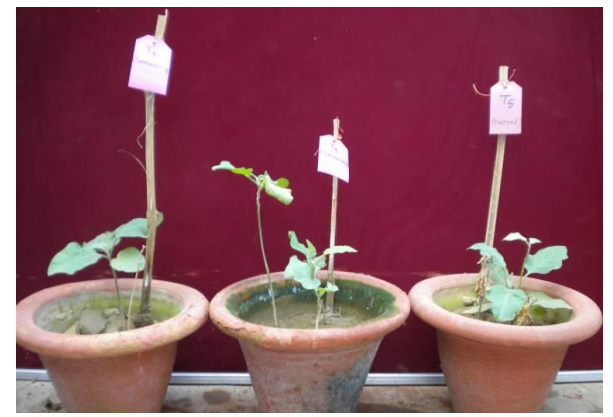

Seed treatment of Carbendazim 50\% WP @2 g/kg seed (T4)

Fig. 5. Effect of different concentration of Bacillus subtilis against $P$. aphanidermatum (Pot experiments) 
The results of the experiment conducted under field conditions revealed that all the treatments with Bacillus subtilis significantly reduced the pre emergence and post emergence damping off disease on brinjal when compared to control (Table 3). Among the various treatments, Seed treatment with liquid formulation of Bacillus subtilis@10 $1 / \mathrm{kg}$ seed recorded the least disease incidence of 7.40 and 8.00 percent pre and post emergence damping off respectively followed by the dosage levels with $20 \mathrm{ml} / \mathrm{kg}$ seed and $5 \mathrm{ml} / \mathrm{kg}$ of seeds in the decreasing order of merit as against pre and post emergence damping off of 33.3 and 50.0 percent respectively in control. Further, the dosage levels of $10 \mathrm{ml}$ and $20 \mathrm{ml}$ were significantly superior in their effect in reducing the pre emergence as well as post emergence damping off. Hence, the dosage level with $10 \mathrm{ml} / \mathrm{kg}$ of seeds itself is enough to manage the damping off disease successfully (Table 3 ).

Table 3. Bio efficacy of Bacillus subtilis for the management of $P$. aphanidermatum causing damping off on Brinjal under field conditions (Rabi Season)

\begin{tabular}{|c|c|c|c|c|c|}
\hline \multirow{2}{*}{$\begin{array}{l}\text { Tr. } \\
\text { no. }\end{array}$} & \multirow[t]{2}{*}{ Treatment details } & \multicolumn{2}{|c|}{ Damping off incidence (\%) } & \multicolumn{2}{|c|}{ Disease control (\%) } \\
\hline & & $\begin{array}{l}\text { Pre } \\
\text { emergence }\end{array}$ & $\begin{array}{l}\text { Post } \\
\text { emergence }\end{array}$ & $\begin{array}{l}\text { Pre } \\
\text { emergence }\end{array}$ & $\begin{array}{l}\text { Post } \\
\text { emergence }\end{array}$ \\
\hline T1 & $\begin{array}{l}\text { Seed treatment with B. subtilis } \\
\text { @ } 5 \mathrm{ml} / \mathrm{kg} \text { seed }\end{array}$ & 18.5 & 22.7 & 44.4 & 55.0 \\
\hline T2 & $\begin{array}{l}\text { Seed treatment with } B . \text { subtilis } \\
@ 10 \mathrm{ml} / \mathrm{kg} \text { seed }\end{array}$ & 7.40 & 8.00 & 77.7 & 84.0 \\
\hline T3 & $\begin{array}{l}\text { Seed treatment with } B \text {. subtilis } \\
\text { @ } 20 \mathrm{ml} / \mathrm{kg} \text { seed }\end{array}$ & 11.1 & 12.5 & 66.6 & 75.0 \\
\hline T4 & $\begin{array}{l}\text { Seed treatment of Carbendazim } \\
50 \% \text { WP @ } 2 \mathrm{~g} / \mathrm{kg} \text { seed }\end{array}$ & 25.9 & 35.0 & 22.2 & 30.0 \\
\hline T5 & $\begin{array}{l}\text { Untreated Control } \\
\text { SE } \\
\text { CD }(p=0.05)\end{array}$ & $\begin{array}{l}33.3 \\
0.18 \\
0.43\end{array}$ & $\begin{array}{l}50.0 \\
0.22 \\
0.52\end{array}$ & - & $\begin{array}{l}- \\
-\end{array}$ \\
\hline
\end{tabular}

Table 4. Effect of seed treatment with Bacillus subtilis on the biometrics of Brinjal crop under field conditions (Rabi Season)

\begin{tabular}{|c|c|c|c|c|c|c|}
\hline $\begin{array}{l}\text { Tr. } \\
\text { no. }\end{array}$ & Treatment details & $\begin{array}{l}\text { Germination } \\
(\%)^{*}\end{array}$ & $\begin{array}{l}\text { Shoot } \\
\text { length } \\
\text { (cm)* }\end{array}$ & $\begin{array}{l}\text { Root } \\
\text { length } \\
(\mathrm{cm})^{*}\end{array}$ & $\begin{array}{l}\text { Vigour } \\
\text { Index }\end{array}$ & $\begin{array}{l}\text { Yield } \\
\text { Mt/ha* }\end{array}$ \\
\hline T1 & $\begin{array}{l}\text { Seed treatment with B. subtilis } \\
@ 5 \mathrm{ml} / \mathrm{kg} \text { seed }\end{array}$ & 81.48 & 54.0 & 21.3 & 6135.44 & 15.65 \\
\hline $\mathrm{T} 2$ & $\begin{array}{l}\text { Seed treatment with B. subtilis } \\
@ 10 \mathrm{ml} / \mathrm{kg} \text { seed }\end{array}$ & 92.59 & 59.3 & 24.3 & 7740.52 & 22.67 \\
\hline T3 & $\begin{array}{l}\text { Seed treatment with B. subtilis } \\
@ 20 \mathrm{ml} / \mathrm{kg} \text { seed }\end{array}$ & 88.88 & 55.3 & 21.6 & 6834.87 & 20.10 \\
\hline T4 & $\begin{array}{l}\text { Seed treatment of Carbendazim } \\
50 \% \text { WP @ } 2 \mathrm{~g} / \mathrm{kg}\end{array}$ & 74.07 & 51.0 & 15.6 & 4933.06 & 12.85 \\
\hline T5 & $\begin{array}{l}\text { Untreated Control } \\
S E \\
C D(p=0.05)\end{array}$ & $\begin{array}{l}66.66 \\
0.21 \\
0.49\end{array}$ & $\begin{array}{l}50.3 \\
0.20 \\
0.48\end{array}$ & $\begin{array}{l}13.3 \\
0.20 \\
0.46\end{array}$ & $\begin{array}{l}4239.57 \\
-\end{array}$ & $\begin{array}{l}8.09 \\
-\end{array}$ \\
\hline
\end{tabular}

Table 5. Estimation of protein in Brinjal plants treated with different concentration of Bacillus subtilis

\begin{tabular}{llll}
\hline Tr. & Treatment details & \multicolumn{2}{c}{ Protein concentration $(\mathbf{m g} / \mathrm{ml})$} \\
\cline { 3 - 4 } no. & & Field trial & Pot Trial \\
\hline $\mathrm{T}_{1}$ & Seed treatment with B. subtilis @ $5 \mathrm{ml} / \mathrm{kg}$ seed & 0.34 & 0.12 \\
$\mathrm{~T}_{2}$ & Seed treatment with B. subtilis @10 ml/kg seed & $\mathbf{0 . 4 4}$ & $\mathbf{0 . 3 0}$ \\
$\mathrm{T}_{3}$ & Seed treatment with B. subtilis @20 ml/kg seed & 0.35 & 0.26 \\
$\mathrm{~T}_{4}$ & Seed treatment of Carbendazim 50\% WP @ 2 g/kg seed & 0.30 & 0.07 \\
$\mathrm{~T}_{5}$ & Untreated Control & 0.18 & 0.06 \\
\hline
\end{tabular}




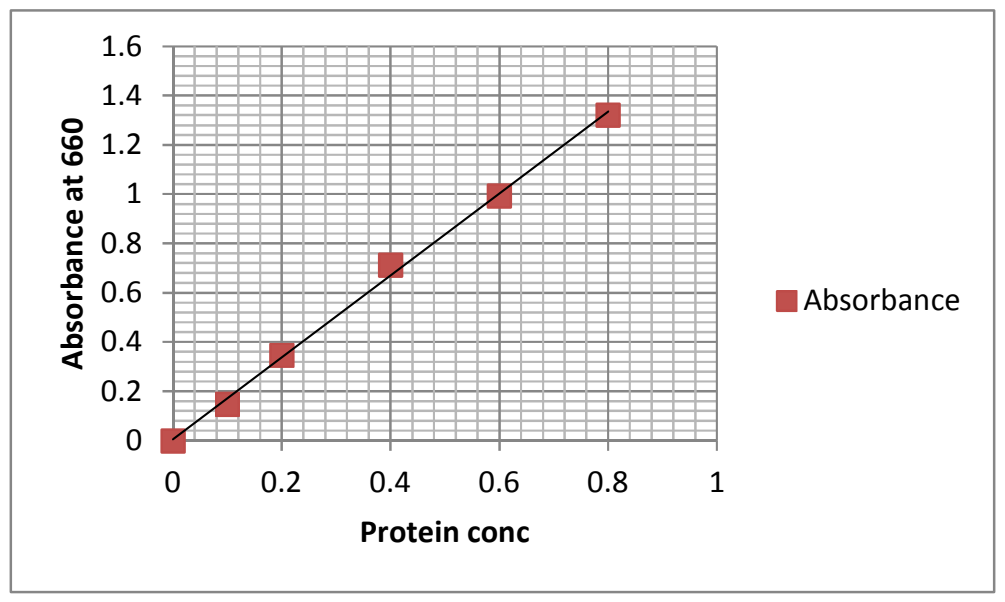

Fig. 6. BSA standard curve

\section{DISCUSSION AND CONCLUSION}

Among the various diseases; Damping-off caused by Pythium aphanidermatum is one of the most widely spread and prevalent throughout the country causing considerable loss in India.

It is extremely difficult to control soil-borne fungi via conventional strategies such as the use of synthetic fungicides, etc. Since their spores are able to survive for many years in the soil, biological control strategies for this pathogen should, therefore, be carefully selected and handled in an eco-friendly way instead of using chemical fungicides. The application of microorganisms as biocontrol agents is important, since they may increase beneficial microbial activity which extends for a long period of time. A group of bio-fertilizers, in dried powder formulations, also known as plant growthpromoting rhizobacteria (PGPR), have been applied to seeds and soil successfully for a number of years [15]. Root-colonizing plantbeneficial bacteria and fungi may provide good protection for plants against root-attacking pathogens [3]. In the last decade, many strains of plant growth-promoting rhizobacteria were reported to induce systemic resistance against a broad spectrum of soil-borne and foliar pathogens. The plant and bacterial interactions in the rhizophere are important for plant health and resistance to disease [15].

As per the screening test, Bacillus subtilis has shown the best antagonistic behaviour against Pythium aphanidermatum in comparison of carbendazim. Similar results were also reported by Smith \& Saddler, [16], Jayaraj and
Radhakrishnan [17], Kabdal et al. [18]. Bacillus subtilis proved to be a dominant biological control agent against Pythium aphanidermatum.

Bacillus subtilis treated plants also showed the highest germination percentage, plant height, root length, and yield per treatment as well as total protein. Similar results on increased plant growth due to application of antagonistic bacteria was reported by [19], 1977 and Turner and Backman, [20]. The increase in bio-matter production may be due to the production of plant growth promoters or through indirect stimulation of nutrient uptake and by producing antibiotics to protect plants from deleterious rhizosphere organisms. Therefore, the antagonist Bacillus subtilis is chosen to be the most promising biocontrol agent against for Pythium aphanidermatum for management of damping off disease. On the basis of present study Bacillus subtilis, might be exploited for sustainable disease management programs to save environmental risk.

From the findings of the present investigation it can be concluded that Bacillus subtilis, @10 $1 / 1$ showed promising performance against Pythium aphanidermatum among all the treatments.

The inhibitory effect of Bacillus subtilis on plant pathogenic fungi has been frequently reported in laboratory, greenhouse, and field studies by various workers $[21,22,23]$. Besides the antifungal effects, some compounds produced by $B$. subtilis may also act as plant growth promoters [24]. Sometimes $B$. subtilis secretes some toxins and enzymes injurious to pathogenic organisms. Moreover, it can directly parasitize other soil 
borne pathogens. This mycoparasitism might be the reason of controlling damping off pathogen in brinjal. This bio-control agent could be used as an eco-friendly approach and may be advised to the farmer for profitable organic farming.

\section{COMPETING INTERESTS}

Authors have declared that no competing interests exist.

\section{REFERENCES}

1. Benbrook CM, Groth E, Halloran JM, Hansen MK, Marquardt S. Pest Management at the Crossroads, Consumers Union, Yonkers. 1996;272.

2. Cook RJ. Making greater use of introduced microorganisms for biocontrol control of plant pathogens. Annual Review of Phytopathology. 1993;31:53-80.

3. Defago G, Haas D. Pseudomonads as antagonists of soil-borne pathogens; mode of action and genetic analysis. Soil Biochemistry. 1990;6:249-291.

4. Dobbelaere SJ, Vanderleyden, Okon Y. Plant growth-promoting effects of diazotrophs in the rhizosphere. Critical Review of Plant Science. 2003;22:107149.

5. Biswas JC, Ladha JK, Dazzo FB. Rhizobia innoculation improves nutrient uptake and growth of low land rice. Soil Science Society of American Journal. (ELSEVIER) 2000;64:1644-1650.

6. Johnsson L, Hökeberg M, Gerhardson B. Performance of the Pseudomonas chlororaphis biocontrol agent MA 342 against seed-borne diseases in field experiments. European Journal of Plant Pathology. 1998;104:701-711.

7. Johnson LF, Curl EA. Methods for research on the ecology of soil borne plant pathogens. Burgess Publishing Company Minneapolis. 1972; 247.

8. Miller JJ. The taxonomic problem in Fusarium with particular reference to Section Elegans. Canadian Journal of Research. 1946; 24:213-223.

9. Morton DT, Stroube WH. Antagonistic and stimulatory effects of microorganism upon Sclerotium rolfsii. Phytopatholgy. 1955;45: 419-420.

10. Srivastava RK, Prasad RD, Rangeshwaran R, Wasnikar AR, Singh SP, Rao NS. A rapid in vivo bioassay method for testing and selection of fungal antagonists of plant pathogens. Journal of Biological Control. 2002;16:173-176.

11. Baki A, Anderson JP. Vigour determination in soyabean seed by multiple criteria. Crop Science. 1973;13:630-633.

12. Goggin DE, Powel SB, Steadman KJ. Selection for low or high primary dormancy in Lolium rigidium gaud seeds results in constitutive differences in stress protein expression and peroxidase activity. Journal of Experimental Botany. 2011;62:10371047.

13. Lowry $\mathrm{OH}$, Rosebrough NJ, Farr AL, Randall RJ. Protein measurement with the folin phenol reagent. Journal of Biological Chemistry. 1951;193:265-275.

14. Trivedi S, Gurha SN. Variations in Fusarium oxysporum f. sp. ciceri isolates from Jhansi district of Bundelkhand, Uttar Pradesh. Journal of Mycology \& Plant Pathology. 2007;37:324-326.

15. Kloepper JW, Rodriguez-Kabana R, Zehnder GW, Murphy JF, Sikora E, Fernandez C. Plant root-bacterial interactions in biological control of soil borne diseases and potential extension to systemic and foliar diseases. Australasian Plant Pathology. 1999;28:21-26.

16. Smith JJ, Saddler GS. The use of a virulent mutants of Ralstonia solanacearum to control bacterial wilt disease. Biotic interaction in plantpathogen associations (Eds. M. J. Jeger and N. J. Sponce). CAB International, Bioscience UK Center. 2001;9:159-176.

17. Jayaraj J, Radhakrishnan NV. Enhanced activity of introduced bio-control agents in solarized soils and its implications on the integrated control of tomato damping-off caused by Pythium spp. Plant Soil. 2008; 304:189-197.

18. Kabdal P, Hooda KS, Joshi D, Hedau NK, Pandey KN. Biocontrol agents in the health management of Capsicum nursery. Indian Journal of Horticulture. 2010;67:70-72.

19. Broadbent P, Baker KF, Franks N, Holla. Effect of Bacillus spp. on increased growth of seedling in steamed and in non-treated soil. Phytopathology. 1977;67:1027-34.

20. Turner JT, Backman PA. Biological cultures tests control. Plant Disease. 1986; 1:49.

21. Pusey PL, Wilson CL. Postharvest biological-control of stone fruit brown rot by Bacillus subtilis plant disease. International Journal of Food Microbiology. 1984;68: 753-756. 
22. Cubeta MA, Hartman GL, Sinclair JB. Interaction between bacillus-subtilis and fungi associated with soybean seeds. Plant Disease. 1985;69:506-509.

23. Bettiol W, Kimati $H$. Effects of Bacillussubtilis on pyricularia-oryzae, causal agent of rice blast. Pesquisa Agropecuaria Brasileira. 1990;25:1165-1174.
24. Compant S, Duffy B, Nowak J, Clement C, Barka EA. Use of plant growth-promoting bacteria for biocontrol of plant diseases: Principles, mechanisms of action, and future prospects. Applied and Environmental Microbiology. 2005;71: 4951-4959.

(c) 2019 Awasthi et al.; This is an Open Access article distributed under the terms of the Creative Commons Attribution License (http://creativecommons.org/licenses/by/4.0), which permits unrestricted use, distribution, and reproduction in any medium, provided the original work is properly cited.

Peer-review history:

The peer review history for this paper can be accessed here: http://www.sdiarticle3.com/review-history/38502 